\title{
Hearing Risk from Noise Levels in a Hospital Neonatal Unit
}

\section{J L Mayes*}

Audiologist, Delta, Canada

Submission: October 23, 2019; Published: October 31, 2019

*Corresponding author: J L Mayes, Audiologist, Delta, BC, Canada

\section{Letter to Editor}

\section{Dear Editor,}

I have read the case report entitled "Measurement of Noise Levels in a Hospital Neonatal Unit in Costa Rica" by Juan, CO, Paula, SC, and Carolina, MN published in the Global Journal of Otolaryngology $(2019 ; 19(4)$ : 556018). I want to congratulate the authors for this important work and contribute regarding the conclusion.

It was indicated noise levels exceeding 80 decibels do not have potential intensity to cause noise-induced hearing loss. The World Health Organization globally recommended daily average exposure limit to prevent noise-induced hearing impairment is 70 decibels [1].

Although it was not the focus of this case report, sound pressure levels inside incubators may also exceed American Paediatric Association recommended noise level limits [2,3].

\section{Conflict of Interest}

J L Mayes receives royalties for hearing health related books.

\section{References}

1. Fink D J (2017) What is a safe noise level for the public? Am J Public Health 107(1): 44-45.

2. WHO (2018) Environmental noise guidelines for the European region? WHO Regional Of Gice for Europe.

3. Fernandez Zacarias F, Beira Jimenez J L, Bustillo Velazquez Gaztelu P J, Hernandez Molina R, Lubian Lopez S (2018) Noise level in neonatal incubators: A comparative study of three models. International Journal of Pediatric Otorhinolaryngology. 107: 150-154.

\begin{tabular}{l} 
Your next submission with Juniper Publishers \\
will reach you the below assets \\
- Quality Editorial service \\
- Swift Peer Review \\
- Reprints availability \\
- E-prints Service \\
- Manuscript Podcast for convenient understanding \\
- Global attainment for your research \\
- Manuscript accessibility in different formats \\
( Pdf, E-pub, Full Text, Audio) \\
- Unceasing customer service \\
Track the below URL for one-step submission \\
https://juniperpublishers.com/online-submission.php \\
\hline
\end{tabular}

